\title{
Carcinoma of the Conjunctiva pT4 TNM
} Finding v7

National Cancer Institute

\section{Source}

National Cancer Institute. Carcinoma of the Conjunctiva pT 4 TNM Finding v7. NCI

Thesaurus. Code C88596.

Carcinoma of the conjunctiva with tumor invading the orbit with or without further extension. (from AJCC 7th Ed.) 